\title{
Buddhist Welfare Organization in Bangladesh
}

\author{
: It's Role in the Modern Society
}

\section{Gyana Ratna SRAMAN}

As far as my knowledge there are thousand over Buddhist Welfare Organizations in Bangladesh, but by nationally and internationally known very few of them. The following organizations are among them-

1) Bangladesh Buddhist Association (BBA): Bangladesh Buddhist Association was established in the year of 1887 by the leadership of late Venerable Gunamizu Mahā thera. ${ }^{1)}$ Among the Buddhist Social Welfare Organizations of Bangladesh this organization is the pioneer. But now BBA have country wide branches and working for the welfare of the country as well as for the Buddhist society. ${ }^{2)}$ Sometimes this association was able to reintroduce Pāli the Theravāda text and literature in the Buddhist populated schools and colleges. For economical development of the Buddhist community this association established a Buddhist Bank ${ }^{3)}$ also. But this bank was unsuccessful project. At present BBA running Chittagong Buddhist Monastery, Chittagong Pāli College, Chintāmuni Library and DhammabaGgsha Educational Institution.

2) Bangladesh Boudha Kristi Prachar Sangha (BBKPS): It was established in the year of 1949. ${ }^{4)}$ The founder of the organization is late Venerable Visuddhānandha Mahāthera. After liberation war of Bangladesh this organization set up one orphanage ${ }^{5)}$ and two temples ${ }^{6}$ in Dhaka and Chittagong. By the direct leadership of BBKPS they established Dhammarājika High School in Dhaka, 25 seated Medical in Dhaka, Technical Training Center in Dhaka, Patiyā High School at Patiyā, Chittagong, Agrasār Girl College at Raozan, Chittagong, PoduA Degree College at Rangunia, Chittagong and they also set up a Pilgrimage shelter center at Buddhagayā, Bihār, India. ${ }^{7)}$

3) Bangladesh Bouddha Juba Parishad (BBJP): This Organization was established in 1967. ${ }^{8)}$ For the young people I think this is only one Buddhist organization in the city area at that time. At present they have national wide branches in Dhaka, Chittagong, Rāngāmāti and Bāndharvan districts. Among their activities every year they are observing 
Buddhist cultural functions, meditation program, seminar, conference, free medical treatment in the city and village area and plantation program. ${ }^{9)}$

4) Abhurkil Janakalyān Samiti (AJS) : Mostly working in the village name Abhurkhil. Dr. Bikiron Prasād Baruā is the pioneer of this Organization. For the development of the village Dr. Baruā and others were established the Organization. This Organization is recently introduced a credit system in the village area. Beside that AJS are also serving religious, social, cultural and national functions to the society too.

5) Pārbatya Bhikkhu Sañgha (PBS) : It was established in $1974,{ }^{10)}$ which is mainly a Buddhist Monks Organization of Chittagong Hill Tracts. They established one distressed children Home in Chittagong Hill Tracts. The distressed child home "Moanoghar" by name established in 1974 by Venerable Jnānashree Mahāthera along with Bimal Bhikkhu and Venerable Prajnānandha Mahāthera. ${ }^{11)}$ Moanoghar Children's Home, Moanoghar Residential School, Moanoghar Pre-Cadet School, Carpentry/Wood Working Training Center, Moanoghar Mini Hospital, Moanoghar Central Libray, Moanghar Weaving Center, Moanoghar Workshop, Afforestation Program, Rice Fields, Horticulture Program (proposed), Moanoghar Departmental Store (proposed), Moanoghar Ice Factory and Cold Storage (proposed).

6) Mahāmandal Welfare Organization-Bangladesh (MWO) : The founder president of the MWO-Bangladesh Most Venerable Prof. Prajnā Bangsha Mahāthera is the pioneer of the organization, which was established in the year of $1976 .{ }^{12)}$ It undertakes different projects plan for the welfare of the society and enlistment of morality and aesthetics way of the humanity. They are: ${ }^{13)}$ (1) Refundable monetary support to the small businessmen and women, (2) Monetary support to the children and poor students, (3) Old Men's Home (support to the poor, helpless and homeless old peoples), (4) Vocational Technical Training Center, (5) Bhikkhu Training and Meditation Center (6) Amity Forest Meditation Center at Kātāchari, and Betbunia Rangamati, (7) International Forest Vipassanā Meditation Center at Baradātilla, Pāhārtali, CTG, (8) MWO Morning School (monastery based) (9) Gaura Chandra Jatindra High School at Kadalpur, (10) Shākyamuni Vihāra at Chittagong City (11) The Buddhist Co-Operative Saving and Money-lending Association Limited, (12) Publication Projects.

\section{Conclusion}

The above are the brief discussion about Buddhist Social welfare Organization in Ban- 
gladesh and their roles in the modern society. After the liberation war of Bangladesh Buddhist people are slowly raising their interest to extent their development in the field of education, custom and culture, economic, politics, as well as religion. Therefore, Buddhist monks and lay followers are gathered in a common issues to eradicate the poverties from the society, to awake the people in the field of education, custom and culture, economic, politics, religion and consciousness of own identity through the social welfare organizations. Without Buddhist Social Welfare Organizations, I think it is very hard to protect the society, custom and culture, religion as well as own identity. To protect and promotion of the own identity Buddhist Social Welfare Organization of Bangladesh have to work more concretely and hardly; and take "welfare" as a challenge in the 21 st century.

1) This report has been found in the various periodical of BBA and quarterly newspapers.

2) This temple is situated nearby Enayet Bazar. Therefore, many People also called it Enayet.

3) To give loan to the Buddhist community, I think this the 1st time any Buddhist association was undertaken the program.

4) Pranab Kumār Baruā : Activities Report of Bouddha Kristi Prachar Sangha. Dhaka 1996, p. 1.

5) Dhammarājika Anātāloy in Dhaka.

6) Dhammarājika Buddhist Monastery, Kamalapur, Atish Dipankara Road, Shabujbug, Dhaka 1214 was established in 1960 and Kātālgonj Buddhist Temple at Chittagong was established in 1978.

7) Pranab Kumār Baruā : Activities Report of Boudha Kristi Prachar Sañgha. Dhaka 1996, p. 6.

8) 33 Anniversaries and Youth Conference 2000 Souvenir : Bangladesh Bouddha Juba Parishad. Dhaka 2000, p. 32 .

9) ibid., p. 56-68.

10) Moanoghar pamphlet, Rangapani, Rangamati Hill District, p. 1.

11) ibid., p. 6.

12) The establishment date was found in MWO-Bangladesh web site and their pamphlet.

13) ibid.,

〈Key Words〉 Bangladesh, 近代化, Social Welfare, Buddhist

(Research Fellow, Aichi Gakuin University $(\mathrm{Ph}, \mathrm{D})$ ) 